\title{
PENINGKATAN KEMAMPUAN KOGNITIF DENGAN MODEL PEMBELAJARAN CREATIVE PROBLEM SOLVING DAN MEDIA PEMBELAJARAN MOBILE LEARNING PADA MATERI LISTRIK STATIS
}

\author{
Siti Nurlina Ripani \\ Universitas Siliwangi Tasikmalaya, \\ Jawa Barat, Indonesia \\ Email: sitiripani7@gmail.com
}

\begin{abstract}
ABSTRAK: Penulisan ini bertujuan untuk mendeskripsikan penerapan model pembelajaran Creative Problem Solving (CPS) dengan media pembelajaran mobile learning pada materi listrik statis untuk meningkatkan kemampuan kognitif. Penulisan ini dilatarbelakangi oleh jumlah pengguna aktif smartphone di Indonesia akan mencapai lebih dari 100 juta orang, diantaranya termasuk pelajar dan guru yang sebgian besar hanya digunakan untuk mengakses jejaring sosial dan belum mengambil peranan dalam bidang Pendidikan. Salah satu peranan mobile dalam Pendidikan yaitu penggunaan mobile learning untuk media pendukung pembelajaran. Selain hal tersebut, penulisan ini juga dilatarbelakangi oleh masih kurangnya penguasaan materi sehingga pembelajaran yang diterapkan belum maksimal. Metode yang digunakan dalam penulisan ini adalah dengan studi kepustakaan dengan mengkaji beberapa literatur untuk dianalisis dan dibuat kesimpulan. Hasil penulisan menunjukkan bahwa model pembelajaran creative problem solving yang dipadukan dengan media pembelajaran mobile learning sebagai solusi dari masalah tersebut sehingga dapat meningkatkan kemampuan kognitif. Langkah pada model pembelajaran creative problem solving diantaranya; mengklarifikasi dan menganalisis masalah yang sudah digambarkan secara virtual dalam mobile learning, melakukan proses evaluasidan seleksi untuk menemukan solusi dan masalah yang ditemukan, lalui melakukan implementasi kepada kelompok lain.
\end{abstract}

Kata Kunci: Creative Problem Solving, Mobile Learning, Kemampuan Kognitif

\section{PENDAHULUAN}

Seiring dengan berkebangnya arus globalisasi, duniamengalami perubahan teknologi menuju pada kemajuan zaman dimana diciptakannya teknologi yang memudahkan kegiatan manusia. Salah satunya adalah dengan berkembangnya smartphone (Zaus, 2018). Di kutip dari kemenperin.go.id (dalam Zaus, 2018) mengatakan bahwa pertumbuhan ponsel di Indoneisa mencapai $62 \%$ per tahun dan smartphone dengan OS android mencaapai $50-60 \%$.

Smartphone sangat membantu semua orang mulai dari mempermudah pekerjaan, alat komunikasi, alat tracking inventori pada laboratorium komputer menggunakan NFC/RFID (Hamzah dan Purwati dalam Zaus, 2018)

Menurut Astuti (2017), siswa banyak menggunakan smartphone untuk bermain games dan media sosial, ini akan mengganggu belajar mereka, karena konsentrasinya akan berkurang atau menurun. Siswa lebih fokus untuk melihat smartphone, bahkan kecanduan smartphone. Selain hal tersebut, materi fisika merupakan materi yag berhubungandengan kehidupan seharihari,sehingga guru dituntut mampu menjelaskan konsep tersebut kedalam bentuk nyata (Astusti, 2017). Pembelajaran 
listrik statis merupakan pembelajaran yang berisi tentang materi-materi yang bersifat abstrak (Zaus, 2018). Menurut Astuti (2017) banyak siswa yangbelum bisa metransfer materi tersebut dalam bentuk yang konkret, sehingga pada akhirnya banyak siswa yang malas belajar fisika karena terlalu banyak rumus untukaplikasinya. Jika hanya dengan metode ceramah akan membuat siswa menjadijenuh dan bosan.

Oleh karena itu, model pembelajaran yang digunakan jangan hanya model pembelajaran tradisional yang akan membuat siswa tidak paham dengan materi pembelajaran fisika, sesuai dengan yang dinyatakan oleh Silalahi (dalam Nana, 2019) bahwa $60 \%$ dari siswa berpendapat bahwa fisika adalah pelajaran yang sulit dipahami dan kurang menarik dipelajari. Hal ini dikarenakan model pembelajaran yang sangat sering digunakan adalah model pembelajaran tradisional yakni ceramah, jarang sekali menggunakan model yang bervariasi. Menurut Druxes (dalam Nana, 2019) hal ini menyebabkan isi masa pelajaran Fisika dianggap sebagai bahan hafalan, sehingga siswa tidak memahami konsep yang sebenarnya.

Beberapa masalah tersebut, dapat diselesaikan dengan menggunakan media pembelajaran dan model pembelajaran yang tepat sehingga mempu mengubah mindset siswa mengenai pelajaran fisika.

Menurut Squire (dalam Ibrahim, 2017) media pembelajaran dapat dikembangkan pada perangkat mobile yang mudah dibawa kemana saja seperti smartphone dan tablet. Dengan smartphone konten pembelajaran dapat dikemas dalam bentuk yang lebih menyenangkan dan menantang (Yuniati, 2012). Media pendukung yang dihasilkan tidak hanya monoton dengan teks saja, tetapi juga memuat unsur-unsur multimedia audio/visual bahkan animasi yang memudahkan siswa dalam memahami materi (Zaus, 2018).

Menurut Belina dan Batubara (dalam Ibrahim, 2017) kehadian mobile learning mampu mendukung konsep Pendidikan sepanjang hayat (long life education). Sifat dari mobile learning yang berbasis open source, membuat setiap orang dapat mengembangkan dan menggunakannya sesuai dengan keinginan dan kebutuhan pembelajaran.

Salah satu model yang mampu menjadi solusi yaitu Creative Problem Solving (CPS). Hikmah (dalam Oktaviani, 2015) menyatakaan bahwa penerapan pembelajaran Creative Problem Solving (CPS) dapat meningkatkan hasil belajar fisika dan aktivitas belajar siswa. Membiasakan siswa dalam mencari sendiri jawaban dari permasalahan yang dimunculkan dapat meningkatkan pemahaman konsep dalam pembelajaran fisika.

Maka dalam hal ini, perlunya membahas bagaimana cara menerapkan model pembelajaran Creative Problem Solving dengan media pembelajaran mobile learning untuk meningkatkan kemampuan kognitif dalam materi listrik statis.

\section{METODE PENELITIAN}

Metode yang digunakan dalam penulisan ini berupa studi kepustakaan. Data dikumpulkan untuk dianalisis kemudian disajikan dalam hasil dan pembahasan agar dapat dibuat kesimpulan.

\section{HASIL DAN PEMBAHASAN}

\subsection{Creative Poblem Solving}

Pada model Creative Problem Solving (CPS) digunakan pemusatan pada pengajaran dan keterampilan pemecahan masalah, yang diikuti dengan penguatan keterampilan. Ketikasiswa dihadapkan pada suatu permasalahan maka siswa dapat 
melakukan keterampilan memecahkan masalah untuk memilih dan mengembangkan ide serta pemikirannya. Siswa tidak hanya menggunakan cara menghafal tanpa proses berpikir, tetapi menggunakan keterampilan memecahan masalah yang mengembangkan proses berpikir (Pepkin, dalam Oktaviani, 2015)

Menurut Puccio (dalam Oktaviani, 2015) Creative Problem Solving (CPS) sebagai model keterampilan berpikir yang salah satu fungsinya adalah untuk meningkatkan proses berpikir sehingga lebih mampu dalam mengatasi kesulitankesulitan.

Langkah pada model pembelajaran creative problem solving diantaranya; mengklarifikasi dan menganalisis masalah yang sudah digambarkan secara virtual dalam mobile learning, melakukan proses evaluasidan seleksi untuk menemukan solusi dan masalah yang ditemukan, lalui melakukan implementasi kepada kelompok lain.

\subsection{Mobile Learning}

Menurut Zaus (2018) Mobile learning merupakan bagian dari media pembelajaran. Media pembelajaran mempunyai peranan penting yang digunakan oleh guru untuk menyampaikan materi pelajaran. Tujuan media pembelajaran sebagai alat bantu pembelajaran, dan membantu konsentrasi siswa dalam proses pembelajaran (Astuti, 2017).

Mobile learning tidakhanya berfokus pada media pembelajaran saja, tren mobile learning telah menyoroti empat pusat pembelajaranmobile, yaitu sebagai pedagogi, perangkat teknologi, konteks, dan social interaksi (Crompton dalam Zaus, 2018).

Menurut Georgiev, Georgieva, dan Smrikarov (dalam Yuniati 2012) mobile learning merupakan bagian dari pembelajaran elektronik atau lebih dikenal dengan e-learning.Menurut Yuniati (2012) M-learning atau mobile learning dalah pembelajaran yang unik karena pembelajar dapatmengakses materi, arahan, dan aplikasi yang berkaitan dengan pembelajaran kapnpun dan dimanapun. Hal ini akan meningkatkan pada materi pmbelajaran, membuat pembelajaran menjadi persuasive, dan dapat mendorong motivasi pembelajar kepada pembelajaran sepanjang hayat (lifelong learning).

Mobile learning pada prinsipnya bertujuan untuk mempermudah pembelajar belajar dimana saja dan kapan saja sesuai dengan waktu yang di miliki. Karena mobile learning secara virtual dapat diakses dari mana saja, dengan menyediakan akses untuk seluruh materi-materi pembelajan yang berbeda-beda. Mobile learning juga menyediakan sharing content untuk setiap pengguna dengan menggunnakan konten yang sama dan memungkinkan adanya umpan balik secara insta (Wilson dan Bolliger dalam Ibrahim, 2017).

Hasil pembuatan mobile learning oleh Zaus (2018), terdiri dari:

1) Halaman Splash yaitu halaman awal yang berisi logo dan nama aplikasi

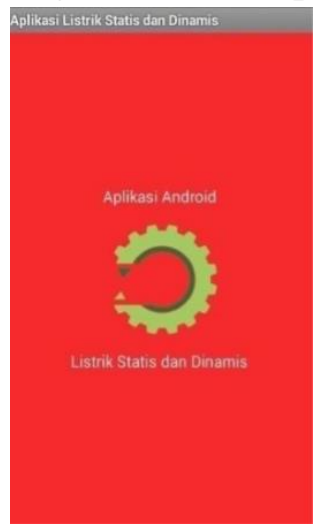

2) Halaman Menu Utama yang terdiri dari materi, latihan, bantuan, tentang dan keluar 


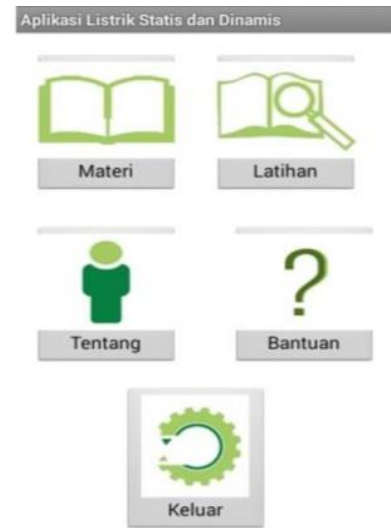

3) Halaman Sub Menu yaitu berisi sub-sub materi dalam suatu materi

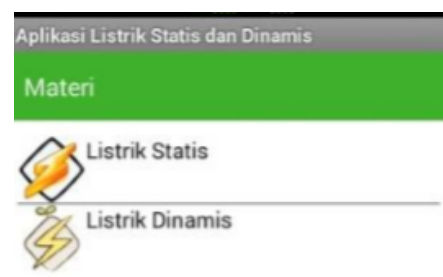

\subsection{Kemampuan Kognitif}

Menurut Yuliani (dalam Jawati, 2013) kemampuan kognitif adalah suatu proses berfikir untuk menghubungkan, menilai dan mempertimbangkan suatu kejadian atau peristiwa.

Sedangkan menunrut Anderson \& Krathwohl (dalam Siswanto dkk, 2014) kemampuan kognitif merupaakan kegiatan mental dari tahap dasar ke tahap yang lebih tinggi yang dilakukan oleh seseorang dalam berpikir yang meliputi aspek mengingat $\left(\mathrm{C}_{1}\right)$, memahami $\left(\mathrm{C}_{2}\right)$, mengaplikasikan $\left(\mathrm{C}_{3}\right)$, menganalisis $\left(\mathrm{C}_{4}\right)$, mengevaluasi $\left(\mathrm{C}_{5}\right)$, dan mencipta $\left(\mathrm{C}_{6}\right)$.

\subsection{Model Creative Problem Solving}

Untuk Meningkatkan Kemampuan Kognitif

Model Creative Problem Solving digunakan pemusatan pada pengajaran dan keterampilan pemecahan masalah, yang diikuti dengan penguatan keterampilan. Ketika siswa dihadapkan pada suatu permasalahan maka siswa dapat melakukan keterampilan memecahkan masalah untuk memilih dan mengembangkan ide serta pemikirannya, tidak hanya menggunakancara menghafal tanpa proses berpikir. Melalui pembelajaran Creative Problem Solvig, siswa mengkonstruksi makna atau pengertian berdasarkan pngetahuan awal yang dimiliki, mengintegrasikan pengetahuan yang baru kedalam skema yang telah ada dalam pemikiran siswa sendiri (Pepkin dalam Oktaviani, 2015).

Hikmah \& Natsir (dalam Oktaviani, 2015) menyatakan bahwa penerapan pembelajaran berbasis masalah dengn tipe CPS dapat meningkatkan ketuntasan belajar siswa. Pembelajaran model Creative Problem Solving dapat meningkatkan kemampuan pemecahan masalah dan aktivitas belajar siswa (Mahardika dalam Oktaviani, 2015).

Dengan hal tersebut, maka model pembelajaran Creative Problem Solving mampu meningkatkan kemampuan kognitif karena membuat siswa berpikir kreatif dan mandiri dan mampu meningkatkan pemahaman konsep, sesuaidengan yang dinyatakan oleh Semiawan (dalam Oktaviani, 2015) bahwa pembelajaran melalui pendekata pemecahan maalah merupakan pembelajaran kognitif induktif yang membuat siswa berpikir kreatif dan mandiri serta dapat meningkatkan pemahaman konsep.

Model pembelajaran CPS memberikan kesempatan seluas-luasnya kepada siswa untuk mengemukakan gagasan kreatifnya untuk menyelesaikan suatu permasalahan (Hikmah dalam Oktaviani, 2015).

\subsection{Model Pembelajaran Mobile \\ Learning Untuk Meningkatkan Kemampuan Kognitif}

E-learning maupun mobile learning umumnya memiliki fitur-fitur pencarian sesuai deengan keinginan pengguna, sehingga berbagai jenis dapat dengan cepat dicari dan ditemukan (Ibrahim, 2017). 
Menurut Jones dan Brown ( dalam Ibrahim, 2017) bahwa salah satu factor penting yang mempengaruhi perpindahan konsepdari sumber belajar cetak (painted) menuju format elektronik (dalam bentuk e-learning maupun mobile learning) yaitu dari segi kemudahan aksesibitasnya.

Menurut Yuniati (2012) konsep pembelajaran mobile learning diharapkan dapat mendorong terwujudnya pembelajaranyang aktif, inovatif, efektif, menyenangkan, gembir, dan berbobot (PAIKEM GEMBROT).

Menurut Shuck (dalam Zaus, 2018) bahwa mobile learning atausmartphone memberi kesempatan untuk memahami pembelajaran di abad-21 dengan cara baru, dengan memanfaatkan ide daripragmatis dan perspektif sociao-cultural.

Dengan media pembelajaran mobile learning dapat meningkatkan kemampuan kognitif atau meningkatkan hasil belajar siswa sesuai dengan penelitian yang dilakukan oleh Surachman dan Surjono (dalam Ibrahim, 2017) bahwa adanya peningkatan hasil belajar sangat efektif setelah menggunakan produk mobile learning.

\section{PENUTUP}

Dari berbagai pembahasan yang telah dijabarkan dapat ditarik kesimpulan dan dimaknai bahwa untuk meningkatkan kemampuan kognitif anak dalam materi listrik statis yang merupakan materi yang bersifat abstrak dapat dilakukan dengan penggunaan model pembelajaran Creative Problem Solving yang menuntut siswa untuk menyelesaikan permasalahannya secara mandiri sehingga mampu meningkatkan pemahaman siswa dan dengan penggunaan media pembelajaran mobile learning yang mampu memotivasi siswa.

\section{UCAPAN TERIMAKASIH}

Terima kasih kepada semua pihak yang telah membantu demi kesempurnaan artikel ini menjadi lebih baik terutama kepada Bapak Dr. Nana, M.Pd. selaku dosen pengampu Fisika Sekolah II atas bimbingannya.

\section{REFERENSI}

Astuti, I. A. D., Sumarni, R. A., \& Saraswati, D. L. (2017). Pengembangan Media Pembelajaran Fisika Mobile Learning berbasis Android. Jurnal Penelitian \& Pengembangan Pendidikan Fisika, 3(1), 57-62

Ibrahim, N., \& Ishartiwi, I. (2017). Pengembangan Media Pembelajaran Mobile Learning Berbasis Android Mata Pelajaran IPA untuk Siswa SMP. Refleksi Edukatika: Jurnal Ilmiah Kependidikan, 8(1)

Jawati, Romaikis. (2013). Peningkatan Kemampuan Kognitif Anak Melalui Permainan Ludo Di PAUD Habibul Ummi II. Spektrum PLS 1(1), 250263

Nana, \& Pramono, H. (2019). Upaya Peningkatan Kemampuan Kognitif dan Komunikasi Ilmiah Siswa Kelas $X$ MIA 1 SMA Negeril Ciamis Menggunakan Model Pembelajaran Inquiry. Difraction 1(1), 1-10

Nana. (2019). PENERAPAN MODEL CREATIVE PROBLEM SOLVING BERBASIS BLOG SEBAGAI INOVASI PEMBELAJARAN DI SEKOLAH MENENGAH ATAS DALAM PEMBELAJARAN FISIKA. Prosiding SNFA (Seminar Nasional Fisika dan Aplikasinya). 3. 190.

10.20961/prosidingsnfa.v3i0.28544. Oktaviani, A.N. \& Nugroho, S.E. (2015). Penerapan Model Creative Problem Solving Pada Pembelajaran Kalor 
Untuk Meningkatkan Pemahaman Konsep dan Keterampilan Komunikasi. Unnes Physics Education Journal 4(1) 26-31

Yuniati, L. (2012). Pengembangan media pembelajaran mobile learning efek doppler sebagai alat bantu dalam pembelajaran fisika yang menyenangkan. Jurnal Penelitian Pembelajaran Fisika, 2(2/septembe)

Siswanto, Kaniawati, I. \& Suhandi A. (2014). Penerapan Model Pembelajaran Pembangkit Argumen Menggunakan Metode Saintifik Untuk Meningkatkan Kemampuan Kognitif dan Keterampilan Berargumentasi Siswa. Jurnal Pendidikan Fisika Indonesia 10 (2), 104-116

Zaus, M. A., Wulansari, R. E., Islami, S., \& Pernanda, D. (2018). Perancangan Media Pembelajaran Listrik Statis dan Dinamis Berbasis Android. INTECOMS: Journal of Information Technology and Computer Science, 1(1), 1-7 